\title{
Oxidative Hemolysis and Erythrocyte Metabolism in Hereditary Acatalasia*
}

\author{
Harry S. Jacob, $†$ Sidney H. Ingbar, and James H. Jandl with the techni- \\ CAL assistance of Susan C. Bell \\ (From the Thorndike Memorial Laboratory and Second and Fourth [Harvard] Medical \\ Services, Boston City Hospital, and the Department of Medicine, \\ Harvard Medical School, Boston, Mass.)
}

Evidence has been presented that Heinz body anemias and possibly normal erythrocyte aging result from oxidative damage to the cell $(1-4)$ and its hemoglobin (1-7) through processes encompassed by the term "oxidative hemolysis" (2). Suggestions that $\mathrm{H}_{2} \mathrm{O}_{2}$ produces such damage in senescent erythrocytes (8) and during drug-induced oxidative hemolysis (9-11) have been advanced but disputed $(2,12)$. Recently two drugs, primaquine and pamaquine, both of which can produce oxidative hemolysis in man, have been reported to generate $\mathrm{H}_{2} \mathrm{O}_{2}$ in vitro (13). In addition, known peroxide-generating compounds $(5,14,15)$ and $\mathrm{H}_{2} \mathrm{O}_{2}$ itself $(14,16,17)$ produce denaturation of hemoglobin in vitro resembling that caused by oxidant hemolytic drugs in vivo (18). Although supportive, these findings do not necessarily indicate that $\mathrm{H}_{2} \mathrm{O}_{2}$ is essential to oxidative hemolysis in vivo. $\mathrm{H}_{2} \mathrm{O}_{2}$, whether added from without or generated endogenously, is degraded in tissues to water and oxygen by catalase.

Instead of being decomposed to water and oxygen by catalase, $\mathrm{H}_{2} \mathrm{O}_{2}$ may alternatively be reduced to water alone when utilized in the peroxidation of hydrogen donor molecules. The latter mechanism is of special interest in erythrocytes, for Mills and his associates $(10,15)$ have demonstrated in the erythrocytes of rats and cows an enzyme, glutathione (GSH) peroxidase, which catalyzes the peroxidation of GSH. Subsequently this enzyme has been reported by some $(17,19)$,

* Submitted for publication November 30, 1964; accepted March 18, 1965.

Supported in part by grants HE-07652-02, T1-AM5391-01, and AM-00267-11 from the National Institutes of Health.

† Address requests for reprints to Dr. Harry S. Jacob, Thorndike Memorial Laboratory, Boston City Hospital, 818 Harrison Ave., Boston, Mass. 02118. although not by others (20), to function in human erythrocytes as well. Unlike catalase, GSH peroxidase efficiently detoxifies low levels of $\mathrm{H}_{2} \mathrm{O}_{2}$, doing so by reversibly oxidizing reduced glutathione (17). If one assumes that other thiols in the erythrocyte are in oxidation-reduction equilibrium with GSH, and since intact globin and membrane thiols are crucial to the integrity of hemoglobin (3) and the survival of the cell $(21,22)$, respectively, this mechanism for detoxifying low levels of $\mathrm{H}_{2} \mathrm{O}_{2}$ demands for preservation of the steady state a compensatory system for restoring glutathione to the reduced state. This compensatory restoration is catalyzed by the enzyme glutathione reductase which, in turn, utilizes as a co-factor TPNH generated in the first two steps of the hexose monophosphate (HMP) shunt. As predicted by Mills and Randall (10) and as demonstrated in vitro by Cohen and Hochstein $(11,17)$, impairment of the HMP shunt by a deficiency of glucose-6-phosphate dehydrogenase (G6PD) results in GSH "instability" in the presence of $\mathrm{H}_{2} \mathrm{O}_{2}$ in vitro, and hemolysis is presumed to follow.

It has recently been suggested (17) that only GSH peroxidation is utilized by erythrocytes in degrading the low concentrations of $\mathrm{H}_{2} \mathrm{O}_{2}$ likely to be present under physiologic conditions. The following studies, performed in several members of a Swiss family with hereditary acatalasia, provide further information concerning the relative utilization of the catalasic versus the peroxidative mechanisms for dissipation of erythrocyte $\mathrm{H}_{2} \mathrm{O}_{2}$. The findings have been reported in a preliminary form elsewhere (23).

\section{Methods}

Subjects. From the "V" family described by Aebi, Heiniger, Bütler, and Hässig (24), two females and one 
male with acatalasia (homozygous) and two males and one female with hypocatalasia (heterozygous) served as erythrocyte donors. In confirmation of the findings of these workers, routine blood values, including reticulocyte percentages, were normal in all family members studied. Methemoglobin and sulfhemoglobin were absent from freshly drawn blood, and there were no inclusion bodies. Cellular concentrations of GSH were normal and were stable when erythrocytes were exposed to acetylphenylhydrazine (18). None of the acatalasic subjects had physical or historical evidence of the severe gangrenous oral infections or other medical difficulties reported in acatalasic Japanese $(25,26)$. The propositus was originally identified in 1961 during a screening study of 38,775 blood samples from Swiss males entering military service. Quantitative analyses of whole blood catalase by a perborate titrimetric method (27) and a spectrophotometric method (28) were previously reported to range from 0.1 to $1.3 \%$ of normal levels in the acatalasic subjects and were roughly $50 \%$ of normal in their hypocatalasic relatives (29). None of the acatalasic hemolysates showed precipitation in Ouchterlony diffusion tests with an anticatalase rabbit serum (29). In the present studies, as judged by a permanganate titration method (30), catalase was absent both in acatalasic erythrocytes and leukocytes. During these studies neither the family members nor the normal donors of blood were receiving medications, except as noted.

Studies in vitro. Fresh blood from family members and from hematologically normal control subjects was drawn into heparin and centrifuged at 3,000 rpm. The buffy coat was removed, and the cells were resuspended in phosphate buffered saline, ${ }^{1} \mathrm{pH}$ 7.4. After recentrifugation and a second removal of any remaining buffy coat, the erythrocytes were suspended in buffered saline to a concentration of $35 \%$. Leukocytes in these washed suspensions numbered less than 1,000 per $\mathrm{mm}^{3}$. When indicated, glucose was added to a final concentration of $0.015 \mathrm{M}$. After removal of a sample of cells for initial metabolic determinations, the remaining cell suspension was incubated at $37^{\circ} \mathrm{C}$ in stoppered vessels with agitation in a water bath. At intervals thereafter samples were removed for further metabolic determinations. In studies requiring incubation for prolonged periods, $500 \mathrm{U}$ of penicillin $\mathrm{G}$ and $250 \mu \mathrm{g}$ of streptomycin were added to each milliliter of sterile washed cell suspension; incubation in such studies was carried out in stoppered tubes kept at $37^{\circ} \mathrm{C}$ without agitation. In all experiments, the metabolism of acatalasic erythrocytes was compared to that of erythrocytes from normal subjects incubated at the same time under identical conditions. The selected oxidant drugs, of reagent grade, were added at 0.1 vol in buffered saline at the onset of incubation. In peroxide diffusion experiments, $30 \% \mathrm{H}_{2} \mathrm{O}_{2}{ }^{2}$ was added to the center wells of Warburg flasks containing the erythrocyte

1 Three parts isotonic saline plus one part isotonic (0.12 M) phosphate buffer, $\mathrm{pH} 7.4$.

2 As Superoxol, Merck and Co., Inc., Rahway, N. J. suspensions, as in the technique described by Cohen and Hochstein (11).

Methemoglobin, sulfhemoglobin, and total hemoglobin were measured on filtered hemolysates by the method of Evelyn and Malloy (31). The appearance of incubated cells was examined microscopically in wet preparations after resuspension in autologous plasma. Supravital staining with aqueous solutions of crystal violet, made isotonic with $\mathrm{NaCl}$, was employed in examinations for inclusion bodies. A semiquantitative assay of precipitated hemoglobin was obtained by comparing the optical density of cyanide-treated hemolysates at $635 \mathrm{~m} \mu$ (" $\mathrm{L}_{2}$ " in the Evelyn-Malloy method) before and after filtration through double thickness Whatman 12 filter paper. From this a "turbidity index" was devised.

$$
\text { Turbidity index }=\frac{L_{0}-L_{F}}{L_{T}}
$$

where $\mathrm{L}_{0}=\mathrm{OD}$ of cyanide-treated hemolysate at $635 \mathrm{~m} \mu$ before filtration, $\mathrm{L}_{\mathrm{F}}=\mathrm{OD}$ of cyanide-treated hemolysate at $635 \mathrm{~m} \mu$ after filtration, and $\mathrm{L}_{\mathrm{T}}=\mathrm{OD}$ of total hemolysate hemoglobin measured as cyanmethemoglobin at 540 $\mathrm{m} \mu$. The $\mathrm{pH}$ of erythrocyte suspensions was measured in a Beckman model $\mathrm{G} \mathrm{pH}$ meter and, when compared over the short periods of incubation, suspensions of acatalasic and normal cells did not differ significantly. Erythrocyte lactate production by the lactate dehydrogenase method $^{3}$ (32), and glucose consumption by the SomogyiNelson (33) or glucose oxidase (34) methods, were determined in duplicate assays from duplicate incubation flasks agitated for 4 hours at $37^{\circ} \mathrm{C}$. Inhibition of erythrocyte GSH by buffered solutions of $N$-ethylmaleimide (NEM) and iodoacetate was effected as described previously (21). The method of Grunert and Phillips (35), as modified by Beutler (36), was used to assay the cellular content of GSH. Measurements of radioactive $\mathrm{CO}_{2}$ derived from cell suspensions incubated with $\mathrm{C}^{14}-1$ glucose ${ }^{4}$ were made utilizing stoppered incubation bottles containing removable plastic wells of hyamine as described previously (37). Briefly, $0.2 \mu \mathrm{c}$ of tracer quantities of $\mathrm{C}^{14}$-glucose was added to $2 \mathrm{ml}$ of a $35 \%$ cell suspension containing $150 \mathrm{mg}$ per $100 \mathrm{ml}$ carrier glucose. After agitation for 4 hours at $37^{\circ} \mathrm{C}, 0.2 \mathrm{ml}$ of $1 \mathrm{~N} \mathrm{H}_{2} \mathrm{SO}_{4}$ was added through the rubber diaphragm covering the incubation bottle. The evolved $\mathrm{C}^{14} \mathrm{O}_{2}$ was trapped in the plastic well containing hyamine and counted in a methanoltoluene solution of 2,5-diphenyloxazole- $p$-bis-2-(5-phenyloxazolyl)benzene 5 in a Packard Tri-Carb liquid scintillation counter. ${ }^{6}$ From a knowledge of the counts of $\mathrm{C}^{14}$ glucose added, the total glucose consumption and the $\mathrm{C}^{14} \mathrm{O}_{2}$

3 Assay reagents produced by Boehringer and Sons Company and obtained in kit form from California Corporation for Biochemical Research, Los Angeles, Calif.

4 Obtained from New England Nuclear Corp., Boston, Mass.

5 Available as Liquifluor, a $25 \times$ concentrated solution, from Pilot Chemicals, Inc., Watertown, Mass.

${ }^{6}$ Generously provided by Dr. Albert Renold of the University of Geneva Medical School. 
TABLE I

Effect of oxidant compounds on normal and acatalasic erythrocytes without glucose*

\begin{tabular}{|c|c|c|c|c|c|c|}
\hline \multirow[b]{2}{*}{ Compound } & \multirow[b]{2}{*}{ Concentration } & \multirow[b]{2}{*}{$\begin{array}{c}\text { Incu- } \\
\text { bation }\end{array}$} & \multicolumn{2}{|c|}{ Normal } & \multicolumn{2}{|r|}{ Acatalasic } \\
\hline & & & $\begin{array}{l}\text { Methe- } \\
\text { moglobin }\end{array}$ & Heinz bodies & $\begin{array}{l}\text { Methe- } \\
\text { moglobin }\end{array}$ & Heinz bodies \\
\hline $\mathrm{H}_{2} \mathrm{O}_{2}$ & $\begin{array}{c}m M \\
\text { Diffusion } \dagger\end{array}$ & $\begin{array}{c}\text { hrs } \\
2 \\
4 \\
4\end{array}$ & $\begin{array}{c}\% \\
0 \\
0 \\
0\end{array}$ & $\begin{array}{l}0 \\
0 \\
0\end{array}$ & $\begin{array}{l}\% \\
19 \\
69 \\
75\end{array}$ & $\begin{array}{l}\text { Present } \\
\text { Present } \\
\text { Present }\end{array}$ \\
\hline Ascorbic acid & $\begin{array}{r}3 \\
5 \\
15\end{array}$ & $\begin{array}{l}4 \\
4 \\
4\end{array}$ & $\begin{array}{l}0 \\
0 \\
0\end{array}$ & $\begin{array}{l}0 \\
0 \\
0\end{array}$ & $\begin{array}{l}17 \\
21 \\
63\end{array}$ & $\begin{array}{l}\text { Present } \\
\text { Present } \\
\text { Present }\end{array}$ \\
\hline Fresh primaquine & $\begin{array}{l}10 \\
10\end{array}$ & $\begin{array}{l}4 \\
4\end{array}$ & $\begin{array}{l}15 \\
28\end{array}$ & $\begin{array}{l}0 \\
0\end{array}$ & $\begin{array}{l}11 \\
30\end{array}$ & $\begin{array}{l}\mathbf{0} \\
\mathbf{0}\end{array}$ \\
\hline $\begin{array}{l}\text { Preincubated } \\
\text { primaquine }\end{array}$ & $\begin{array}{l}10 \\
10\end{array}$ & $\begin{array}{l}4 \\
4\end{array}$ & $\begin{array}{l}50 \\
60\end{array}$ & $\stackrel{0}{0}$ (0\% sulfhemoglobin) & $\begin{array}{l}75 \\
90\end{array}$ & $\begin{array}{c}0 \\
\text { (3\% sulfhemoglobin) }\end{array}$ \\
\hline Hydroquinone & $\begin{array}{l}2 \\
2 \\
2\end{array}$ & $\begin{array}{l}2 \\
2 \\
4\end{array}$ & $\begin{array}{l}10 \\
12 \\
37\end{array}$ & $\begin{array}{l}0 \\
0\end{array}$ & $\begin{array}{l}20 \\
40 \\
80\end{array}$ & $\begin{array}{l}\text { Present } \\
\text { Present }\end{array}$ \\
\hline $\begin{array}{l}\text { Acetylphenyl- } \\
\text { hydrazine }\end{array}$ & $\begin{array}{r}12 \\
5 \\
12\end{array}$ & $\begin{array}{l}2 \\
4 \\
4\end{array}$ & $\begin{array}{l}26 \\
35 \\
52\end{array}$ & $\begin{array}{l}\text { Present } \\
\text { Present } \\
\text { Present }\end{array}$ & $\begin{array}{l}22 \\
34 \\
48\end{array}$ & $\begin{array}{l}\text { Present } \\
\text { Present } \\
\text { Present }\end{array}$ \\
\hline
\end{tabular}

* In these experiments, erythrocytes from three different acatalasic and three different normal subjects are represented. Both cell types were washed and simultaneously incubated with agitation at $37^{\circ} \mathrm{C}$ in the same phosphate buffered saline medium ( $\mathrm{pH}=7.4$ ) containing the oxidant compound.

$\dagger \mathrm{H}_{2} \mathrm{O}_{2}$ was added by continuous vaporous diffusion of $30 \% \mathrm{H}_{2} \mathrm{O}_{2}$ from the center well of Warburg flasks into the surrounding erythrocyte suspension (see Methods).

$\ddagger$ Preincubated primaquine solution was either allowed to stand in air for several hours, or alternatively, irradiated briefly with ultraviolet light (see text); in the latter instance sulfhemoglobin as well as methemoglobin contents of the incubated cells were assayed.

counts produced, the percentage of utilized glucose metabolized to $\mathrm{C}^{14} \mathrm{O}_{2}$ was calculated.

Studies in vivo. Erythrocyte survival studies utilizing erythrocytes labeled with $\mathrm{Cr}^{51}$ sodium chromate ${ }^{7}$ were performed as described previously (38). Washed, labeled erythrocytes from two acatalasic donors were injected into two normal, compatible recipients, and their disappearance was followed for 1 month. As a test of the ability of the primaquine 8 used in these studies to cause oxidative hemolysis in vivo, a daily dose of $30 \mathrm{mg}$ was administered to a normal recipient of $\mathrm{Cr}^{\text {sl }}$-labeled, G6PD-deficient erythrocytes; rapid destruction of the labeled cells was observed after drug ingestion.

\section{Results}

Effects of oxidant drugs on acatalasic erythrocytes. Washed erythrocyte suspensions from acatalasic and normal subjects were incubated simultaneously in identical glucose-free media.

\footnotetext{
7 Available as Rachromate from Abbott Laboratories, North Chicago, Ill.

8 Generously supplied by Dr. George D. Wessinger, Sterling-Winthrop Institute, Division of Sterling Drug, Inc., Rensselaer, N. Y.
}

Oxidant damage by various compounds was assessed by the formation of methemoglobin and the appearance of precipitated hemoglobin inclusions (Heinz bodies) in the incubated erythrocytes. $\mathrm{H}_{2} \mathrm{O}_{2}$ was added to erythrocytes slowly and continuously by diffusion or by the action of various concentrations of ascorbic acid. The latter compound gradually and stoichiometrically generates $\mathrm{H}_{2} \mathrm{O}_{2}$ in the presence of oxyhemoglobin by the process of "coupled oxidation" (5). As shown in Table $\mathrm{I}$, both sources of $\mathrm{H}_{2} \mathrm{O}_{2}$ caused oxidation and denaturation of hemoglobin only in acatalasic cell suspensions. This table demonstrates the specific vulnerability of acatalasic erythrocytes to peroxide-generating compounds and reveals that this vulnerability exists at low, as well as at high (26), concentrations of $\mathrm{H}_{2} \mathrm{O}_{2}$. In contrast, primaquine solution, when freshly prepared, produced similar concentrations of methemoglobin in both cell types. If, however, it was allowed to stand in stoppered glass bottles for 24 hours or irradiated with ultraviolet light for 30 minutes, the oxidant 


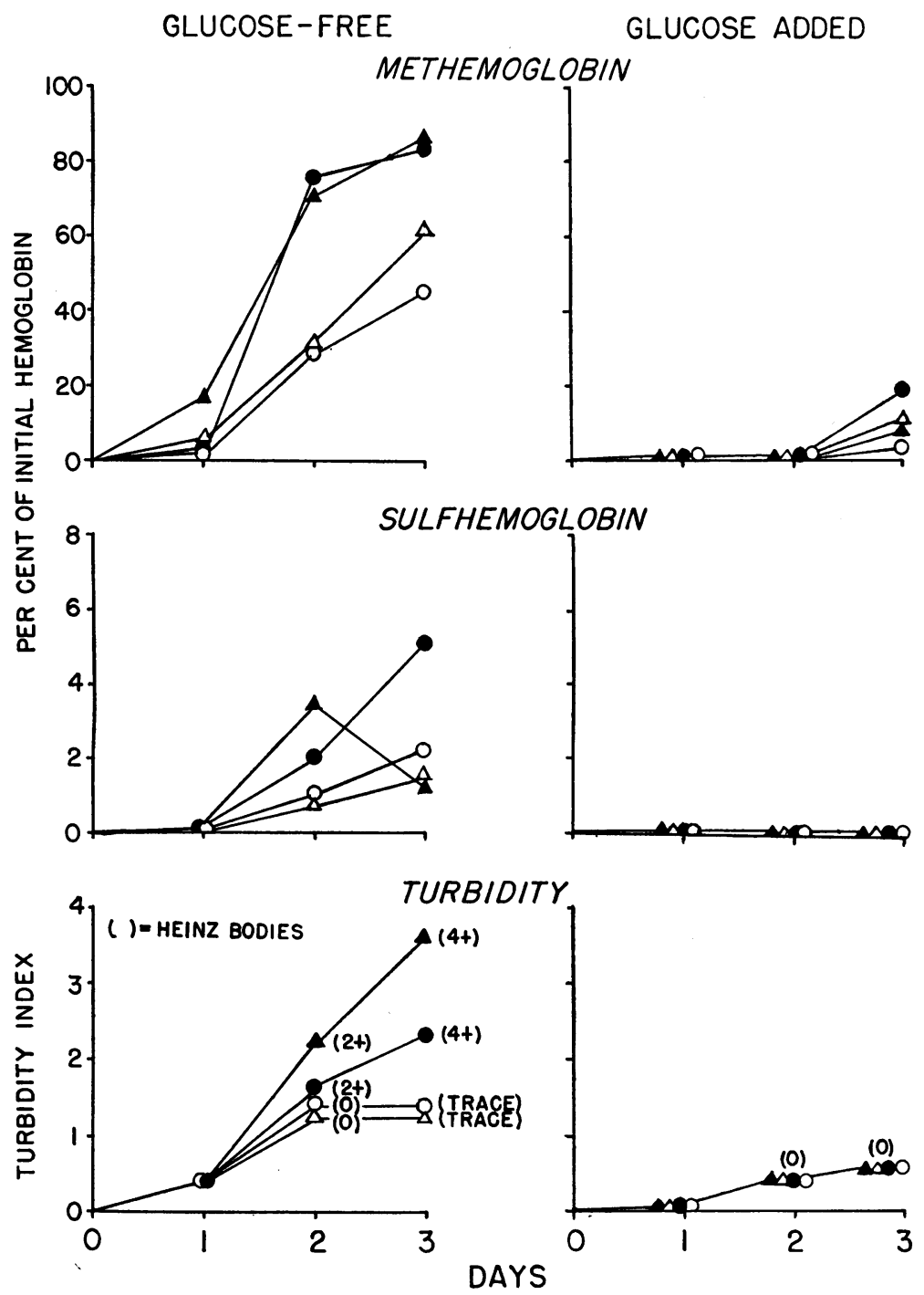

Fig. 1. EFfect of PRolonged incubation on aCATAlasic AND NORMal ERYTHROCYTES. When sterile incubation was performed in glucose-free media (left), erythrocytes from two acatalasic siblings (black symbols) accumulated methemoglobin (upper) and sulfhemoglobin (middle) more rapidly and to greater degree than did those from two normal subjects (white symbols). Denaturation and precipitation of hemoglobin as measured by turbidity (lower) and the formation of Heinz bodies (parentheses) were also more prominent in incubated acatalasic erythrocytes. Glucose addition prevented this hypersusceptibility (right). The experiment portrayed is representative of three performed. Each point represents one determination on a sample of blood from one donor. The drop in sulfhemoglobin level in one of the acatalasic specimens at 3 days without glucose presumably reflects removal of the pigment by its precipitation (2).

potency of primaquine was enhanced, particularly for acatalasic erythrocytes. This was evidenced by their greater accumulation of both methemoglobin and sulfhemoglobin. In the concentration employed, hydroquinone, a postulated intermediate in the in vivo metabolic degradation of primaquine and other 8-amino quinonolones (12), produced Heinz bodies only in acatalasic erythrocytes, in 
which it had generated 2 to 3 times the quantity of methemoglobin generated in normal cells. Finally, both cell types underwent oxidant damage by acetylphenylhydrazine, but acatalasic cells showed no hypersusceptibility to this drug regardless of its concentration.

Effects of prolonged incubation on acatalasic erythrocytes. Under aseptic conditions washed erythrocytes from acatalasic and normal donors were simultaneously incubated under identical conditions for 3 days. In glucose-free media (left portion, Figure 1) methemoglobin appeared sooner and accumulated to a greater extent in acatalasic than in normal erythrocytes (left upper, Figure 1). Similarly, so-called "sulfhemoglobin," a mixture of irreversibly denatured hemoglobin products, accumulated more rapidly in acatalasic cells (left middle portion, Figure 1). Precipitated hemoglobin was estimated by a "turbidity index" (see Methods) and by estimating the number of Heinz bodies. As seen in the lower left portion of Figure 1, the turbidity of hemolysates from incubated acatalasic erythrocytes increased progressively with time and exceeded that from simultaneously incubated normal cell suspensions. Acatalasic erythrocytes contained numerous Heinz bodies after 48 hours of incubation, whereas similarly incubated normal cells contained none. The response of hypocatalasic erythrocytes to prolonged sterile incubation was indistinguishable from that of normal erythrocytes (not shown).

The role of glycolysis in the prevention of oxidative damage to acatalasic erythrocytes. When glucose was added to the erythrocyte suspensions (right portion of Figure 1), acatalasic erythrocytes were no longer hypersusceptible to the oxidative damage of prolonged incubation. Glucose also protected acatalasic erythrocytes from damage due to oxidant drugs. As shown in Table II, the accumulation of methemoglobin in acatalasic cells treated with ascorbic acid was prevented by glucose. Similarly, the oxidation of hemoglobin by primaquine was markedly inhibited by glucose in acatalasic cells, just as it is in normal cells.

The defense of acatalasic erythrocytes from damage by $\mathrm{H}_{2} \mathrm{O}_{2}$ not only required glucose but was associated with an increase in their glycolytic rate, as shown in Table III. Whether added by an $\mathrm{H}_{2} \mathrm{O}_{2}$ diffusion method (D experiments, Table III) or by ascorbic acid addition (A experiments,

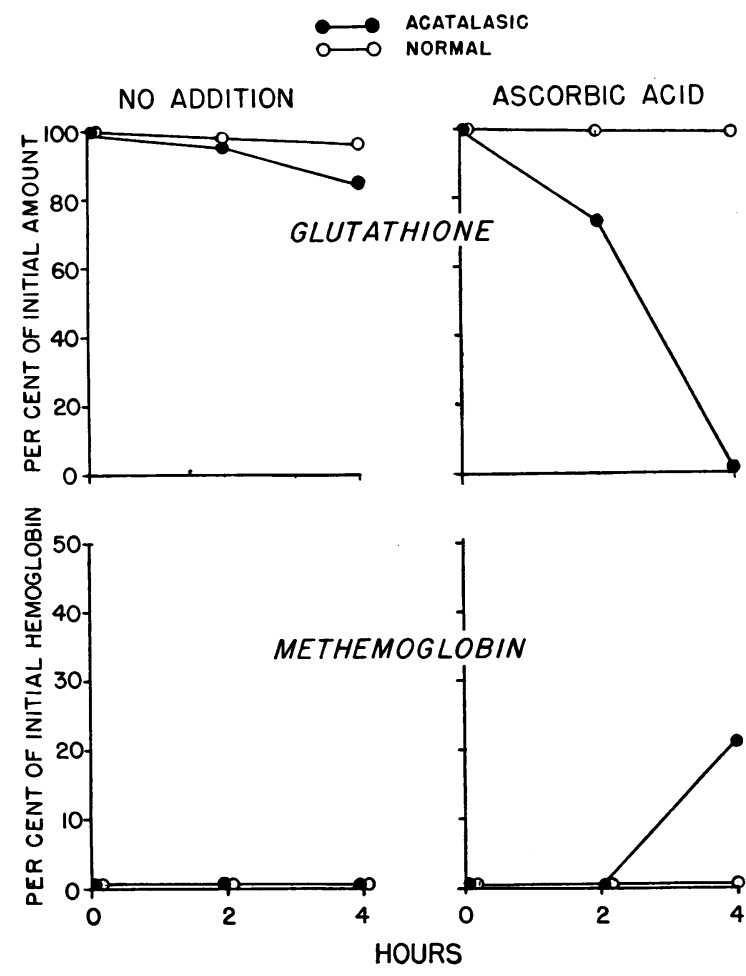

Fig. 2. Comparison of glutathione (GSH) aND HEMOGLOBIN OXIDATION IN ACATALASIC AND NORMAL ERYTHROCYTES. When incubated in glucose-free media (left), cellular GSH (upper) underwent somewhat more oxidation in acatalasic erythrocytes (black circles) than in normal cells (white circles). With ascorbic acid, reduced GSH disappeared (right upper) and methemoglobin accumulated (right lower) rapidly and specifically in acatalasic erythrocytes. The experiment depicted is representative of two performed that utilized erythrocytes from two acatalasic and two normal subjects. Each point represents one determination on a sample of blood from a single donor. Note the sequential oxidation of glutathione and hemoglobin.

Table III), $\mathrm{H}_{2} \mathrm{O}_{2}$ consistently stimulated the rate of glucose consumption by acatalasic erythrocytes. In contrast, in simultaneous experiments, glycolysis of normal cells was unchanged or slightly depressed by $\mathrm{H}_{2} \mathrm{O}_{2}$.

The role of glutathione (GSH) in the metabolism of acatalasic erythrocytes. During incubation without glucose, the GSH content of acatalasic erythrocytes was abnormally unstable. As shown in the upper left portion of Figure 2, GSH diminished somewhat more rapidly in acatalasic cells during 4 hours incubation without glucose than it did in normal cells. This difference became striking when ascorbic acid was added to the cell sus- 


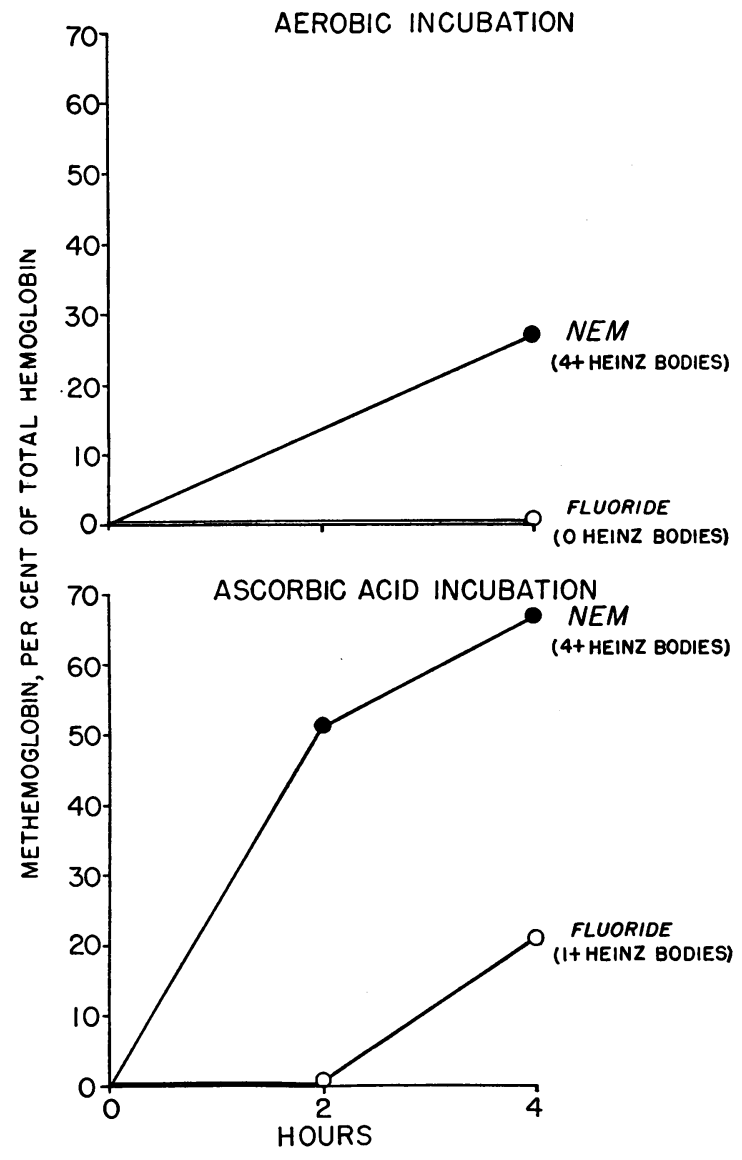

Fig. 3. EFFECT OF SULFHYDRYL INHIBITION ON THE OXIDATION OF HEMOGLOBIN WITHIN ACATALASIC ERYTHROCYTES. Whether incubated in air alone (upper) or with $5 \mathrm{mM}$ ascorbic acid (lower), acatalasic erythrocytes accumulated methemoglobin and Heinz bodies to a greater degree when glutathione was inhibited by $N$-ethylmaleimide (NEM) (black circles) than when glycolysis was inhibited by sodium fluoride (white circles). The experiment depicted is typical of three performed that utilized erythrocytes from two acatalasic and three normal subjects. Each point represents a single determination.

pensions (right upper, Figure 2). Noteworthy was the fact that methemoglobin levels of these acatalasic cells were negligible as GSH was decreasing, but then rose significantly only as GSH activity disappeared (right lower, Figure 2). The disappearance of GSH and the accumulation of methemoglobin was prevented by the addition of glucose to the incubations (not shown).

If cellular GSH was experimentally inhibited, by binding with $N$-ethylmaleimide (NEM), acatalasic erythrocytes became extremely vulnerable to oxidative damage by $\mathrm{H}_{2} \mathrm{O}_{2}$-generating systems. In acatalasic cells, briefly incubated in air, the addition of NEM sufficient to bind all cellular GSH resulted in the accumulation of large quantities of methemoglobin and numerous Heinz bodies (top portion, Figure 3 ). Simple inhibition of glycolysis by $8 \mathrm{mM}$ fluoride had no comparable effect in simultaneously incubated acatalasic cells. When incubated with $5 \mathrm{mM}$ ascorbic acid, the oxidative injury to NEM-treated, acatalasic erythrocytes was rapid and massive, over half of the hemoglobin of these cells being oxidized in 2 hours (lower portion, Figure 3). No methemoglobin was detected at this time in fluoridated cells similarly treated (lower portion, Figure 3 ). After 4 hours the difference in methemoglobin levels of NEM and fluoride-treated cells remained striking, and Heinz bodies were more obviously apparent in the sulfhydryl-inhibited than in the fluoridated cells. Similar results were obtained when iodoacetate replaced NEM as a sulfhydryl inhibitor. In simultaneous experiments NEM was found to produce no oxidation of hemoglobin in normal cells, even when treated with ascorbic acid (not shown).

The hexosemonophosphate (HMP) shunt in acatalasic erythrocytes. Although the over-all rate of glucose utilization was normal in untreated acatalasic erythrocytes, the proportion metabolized via the HMP shunt was increased to approximately thrice normal (Table IV). As noted above, the glucose utilization of acatalasic erythrocytes was greatly increased by exposure to peroxide-generating systems that had no effect on this function in normal cells (Table III). This

TABLE II

Effect of glucose on methemoglobin accumulation in acatalasic erythrocytes*

\begin{tabular}{ccc}
\hline $\begin{array}{c}\text { Oxidant drug } \\
\text { added }\end{array}$ & $\begin{array}{c}\text { Glucose } \\
\text { added }\end{array}$ & $\begin{array}{c}\text { Methe- } \\
\text { moglobin } \\
\% \text { of } \\
\text { total }\end{array}$ \\
\hline $\begin{array}{c}\text { Ascorbic acid } \\
3 \text { mM }\end{array}$ & 0 & 18 \\
Primaquine & + & 0 \\
10 mM & 0 & 23 \\
& + & 4
\end{tabular}

* Two samples of acatalasic erythrocytes in the same medium were incubated simultaneously for 4 hours with the appropriate oxidant drug with or without added glucose. The experiment is typical of two performed. 
TABLE III

Effect of low levels of $\mathrm{H}_{2} \mathrm{O}_{2}$ on the glycolysis of erythrocytes*

\begin{tabular}{|c|c|c|c|c|}
\hline \multirow[b]{2}{*}{ Erythrocytes } & \multirow[b]{2}{*}{$\begin{array}{c}\text { Experi- } \\
\text { ment } \dagger\end{array}$} & \multicolumn{2}{|c|}{ Glucose consumption } & \multirow{2}{*}{$\begin{array}{l}\text { Effect of } \\
\mathrm{H}_{2} \mathrm{O}_{2} \text { on } \\
\text { glucose } \\
\text { consump- } \\
\text { tion } \\
\% \text { change }\end{array}$} \\
\hline & & $\begin{array}{c}\text { No ad- } \\
\text { ditive }\end{array}$ & Peroxide & \\
\hline & \multicolumn{4}{|c|}{$\mu$ moles $/ \mathrm{ml}$ cells $/ \mathrm{hr}$} \\
\hline Normal & $\begin{array}{l}\text { D1 } \\
\text { D1 } \\
\text { D2 } \\
\text { A1 } \\
\text { A1 } \\
\text { A2 }\end{array}$ & $\begin{array}{l}1.81 \\
1.28 \\
1.85 \\
1.21 \\
1.35 \\
1.35\end{array}$ & $\begin{array}{l}1.78 \\
1.25 \\
1.87 \\
0.93 \\
1.00 \\
1.37\end{array}$ & $\begin{array}{r}-2 \\
-3 \\
+1 \\
-23 \\
-26 \\
+2\end{array}$ \\
\hline Acatalasic & $\begin{array}{l}\text { D1 } \\
\text { A1 } \\
\text { A1 } \\
\text { A2 }\end{array}$ & $\begin{array}{l}1.12 \\
1.02 \\
0.89 \\
1.24\end{array}$ & $\begin{array}{l}1.79 \\
2.15 \\
2.02 \\
1.42\end{array}$ & $\begin{array}{r}+60 \\
+113 \\
+127 \\
+14\end{array}$ \\
\hline
\end{tabular}

* Two samples of each erythrocyte suspension from three acatalasic and four normal donors were incubated in parallel with agitation for 4 hours at $37^{\circ} \mathrm{C}$. The suspending medium for each paired incubation was identical and contained $0.015 \mathrm{M}$ glucose with or without added $\mathrm{H}_{2} \mathrm{O}_{2}$.

$\mathrm{H}_{2} \mathrm{O}_{2}$ was added in " $\mathrm{D}$ " experiments by continuous diffusion of $30 \% \mathrm{H}_{2} \mathrm{O}_{2}$ from the center wells of Warburg flasks into the surrounding erythrocyte suspension (see Methods). In " $A$ " experiments, $\mathrm{H}_{2} \mathrm{O}_{2}$ was generated by the addition of $5 \mathrm{mM}$ ascorbic acid directly to the blood suspensions.

increase in the presence of ascorbic acid was entirely through stimulation of the HMP shunt (Table IV). Thus, ascorbic acid doubled the over-all consumption of glucose by acatalasic erythrocytes and stimulated metabolism in the HMP shunt twelvefold. Despite this enhancement formation of lactate by these cells was unaltered. In contrast, both total glucose consumption and the activity of the HMP shunt were little affected in normal cells exposed to the small amount of ascorbic acid utilized in these studies.

From the foregoing it might be predicted that erythrocytes devoid of catalase and also deficient in HMP shunt activity should be extremely vul-

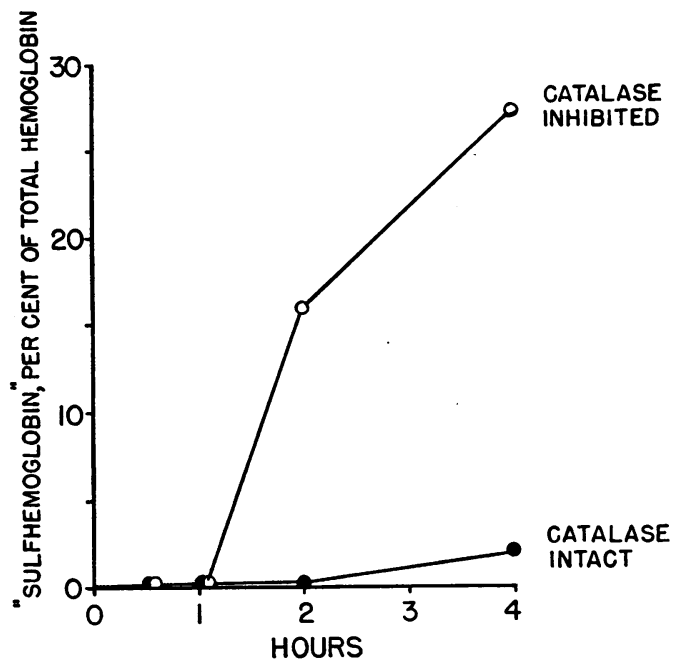

Fig. 4. Effect of catalase inhibition on glucose-6PHOSPHATE-DEH YDROGENASE-DEFICIENT ERYTHROCYTES EXPOSED To $\mathrm{H}_{2} \mathrm{O}_{2}$. The inhibition of erythrocyte catalase by sodium cyanide (white circles) potentiated the oxidative denaturation of hemoglobin to sulfhemoglobin in G6PDdeficient erythrocytes that were exposed to $\mathrm{H}_{2} \mathrm{O}_{2}$ by treatment with $30 \mathrm{mM}$ ascorbic acid. The experiment depicted is representative of five performed, utilizing erythrocytes from two male G6PD-deficient subjects. Each point represents a single determination in blood from one subject.

nerable to oxidant damage by peroxides. This was found to be the case as shown in Figure 4. When erythrocytes from a Negro male with deficiency of glucose-6-phosphate dehydrogenase (G6PD), the first enzyme of the HMP shunt, were incubated with $30 \mathrm{mM}$ ascorbic acid alone, only minimal oxidation of hemoglobin to sulfhemoglobin occurred. In contrast, when the catalase of these cells was inhibited by the preaddition

TABLE IV

Activity of hexosemonophosphate (HMP) shunt in normal and acatalasic erythrocytes

\begin{tabular}{|c|c|c|c|c|c|c|}
\hline Cells & $\begin{array}{c}\text { No. of } \\
\text { incuba- } \\
\text { tions }\end{array}$ & Compound added & Glucose consumption & $\begin{array}{c}\text { Lactate } \\
\text { formation }\end{array}$ & $\begin{array}{l}\text { Conversion } \\
\text { glucose } 1-C^{14} \\
\text { to } \mathrm{C}^{14} \mathrm{O}_{2}\end{array}$ & $\begin{array}{l}\text { Glucose metab- } \\
\text { olized via } \\
\text { HMP shunt* }\end{array}$ \\
\hline & & & Amoles $/ L$ cells $/ h r$ & $\begin{array}{c}\text { mmoles } / L \\
\text { cells } / \mathrm{hr}\end{array}$ & $\%$ & $\underset{\text { cells } / \mathrm{hr}}{\operatorname{mmoles} / L}$ \\
\hline Normal & $\begin{array}{l}2 \\
2\end{array}$ & $\begin{array}{l}\text { None } \\
\text { Ascorbic acid } \\
(5 \mathrm{mM})\end{array}$ & $\begin{array}{r}1,280 \pm 70 \text { (range) } \\
960 \pm 30\end{array}$ & $\begin{array}{l}2,690 \pm 270 \\
2,400 \pm 60\end{array}$ & $\begin{array}{l}3.7 \pm 0.5 \\
6.5 \pm 0.1\end{array}$ & $\begin{array}{l}48 \pm 5 \\
62 \pm 2\end{array}$ \\
\hline Acatalasic & $\begin{array}{l}2 \\
2\end{array}$ & $\begin{array}{c}\text { None } \\
\text { Ascorbic acid } \\
(5 \mathrm{mM})\end{array}$ & $\begin{array}{r}960 \pm 70 \\
2,090 \pm 70\end{array}$ & $\begin{array}{l}1,820 \pm 110 \\
1,880 \pm 470\end{array}$ & $\begin{array}{l}13.0 \pm 1.5 \\
69.3 \pm 5.4\end{array}$ & $\begin{array}{r}123 \pm 5 \\
1441 \pm 67\end{array}$ \\
\hline
\end{tabular}

* This value is a minimal approximation of HMP shunt activity, ignoring the contribution by recycling of carbon fragments other than C-1 through this pathway. 


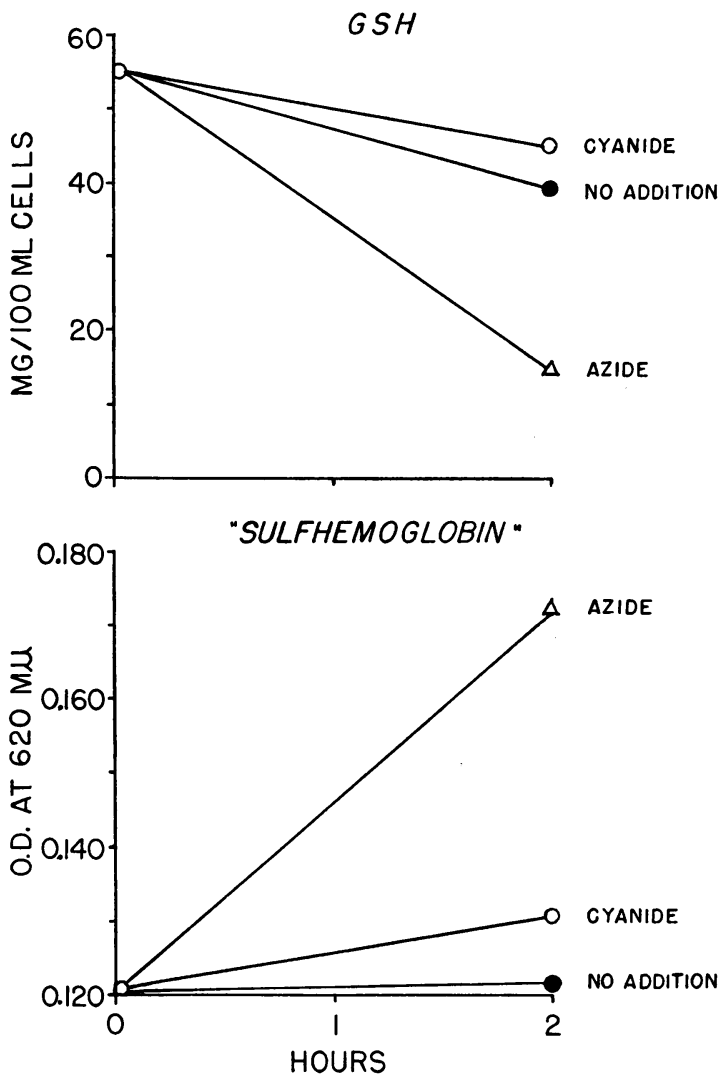

Fig. 5. EFFect of CYANIDE AND AZIDE ON THE OXIDATION OF GLUTATHIONE AND HEMOGLOBIN IN ERYTHROCYTES. Although both are catalase inhibitors, sodium azide $(10 \mathrm{mM})$, but not sodium cyanide $(10 \mathrm{mM})$, promoted oxidation of glutathione (upper) when added to normal erythrocytes incubated for short periods without glucose. Concomitantly, hemoglobin was denatured to sulfhemoglobin-type pigments that absorb after the addition of excess cyanide (lower). The experiment depicted is typical of four performed. Each point represents a single determination.

of $10 \mathrm{mM} \mathrm{NaCN}$, irreversibly denatured hemoglobin pigments accumulated rapidly. Normal erythrocytes treated in similar fashion were unaffected (not shown).

In previous studies of the role of $\mathrm{H}_{2} \mathrm{O}_{2}$ in oxidative hemolysis, azide and cyanide have been extensively utilized as inhibitors of catalase. However, these compounds are not "pure" in this effect, producing other changes in erythrocyte metabolism as well. As shown in Figure 5, azide when added to glucose-free erythrocytes in concentrations necessary to suppress catalase causes the oxidation of GSH (upper portion, Figure 5) and of hemoglobin (lower portion, Figure 5) more rapidly than occurs in cells that are genetically devoid of catalase (Figures 1 and 2). Recently, similar concentrations of this compound have been shown to double the rate of HMP shunt metabolism in erythrocytes (39). In contrast cyanide was found to be a comparably potent inhibitor of catalase without affecting HMP shunt metabolism (39) but tended to stabilize glutathione against autoxidation both within cells (Figure 5) and in solution. In addition, cyanide was found to resist elution from the cells containing methemoglobin more than did azide (40). ${ }^{\circ}$

Effects of primaquine and ascorbic acid ingestion on the survival of acatalasic erythrocytes in vivo. Erythrocytes from two acatalasic donors were labeled with $\mathrm{Na}_{2} \mathrm{Cr}^{51} \mathrm{O}_{4}$ and injected into two normal, compatible recipients. As shown in Figure 6, the survival of cells from one donor (M. V.) during the 13-day period of observation appeared to fall within the normal range, with an estimated half-survival $\left(T_{50}\right)$ of 26 to 30 days, while that from the other (T. V.) may have been slightly decreased ( $T_{50}$, about 21 to 22 days). The survival of cells from both donors was unaffected when relatively large doses of primaquine were ingested daily for 5 days. Similarly, ascorbic acid administered in large doses had no definite effect on the survival of the acatalasic erythrocytes of donor T. V. After these studies it was considered reasonably safe to administer these drugs to the acatalasic patients themselves. The daily ingestion of $6 \mathrm{~g}$ of ascorbic acid or of $120 \mathrm{mg}$ of primaquine produced no alteration in hematocrit, methemoglobin concentration, or reticulocyte percentage in two acatalasic siblings.

9 The affinity of cyanide for methemoglobin exceeds that of azide (5). Ancillary studies (40) have indicated that cyanide competitively displaces azide. Under the conditions of the present experiments, the ratio of cyanide added in the Evelyn-Malloy procedure to azide present in the blood suspensions was $100: 1$; at this ratio it was established that almost all of the ferriheme became complexed with cyanide. Thus in the lower portion of Figure 5 the absorption at $620 \mathrm{~m} \mu$ of hemolysates from blood incubated with azide can be directly compared to cyanide alone. Such absorption reflects the existence of those hemochromes loosely identified as "sulfhemoglobin." 


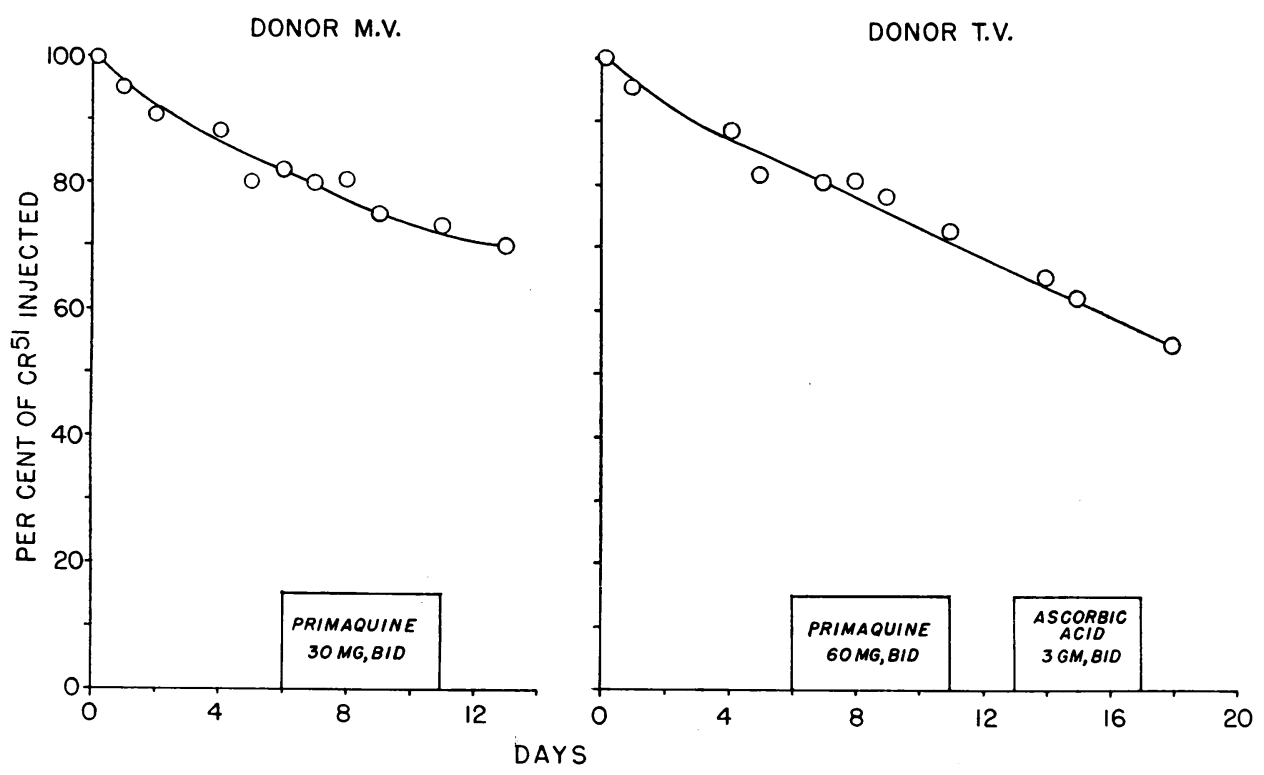

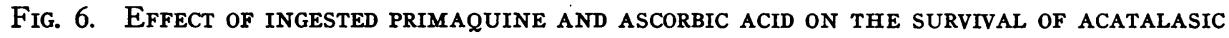
ERYTHROCYTES IN vivo. $\mathrm{Cr}^{51}$-labeled erythrocytes from two acatalasic siblings were injected into two normal compatible recipients. The half survival of labeled cells from patient M. V. (left) fell within the normal range of 26 to 30 days, whereas that of patient T. V. (right) was slightly shortened to 21 to 22 days. Erythrocyte survival was unaffected by large oral doses of primaquine or ascorbic acid.

\section{Discussion}

The present studies help clarify the mechanisms of hemolysis caused by various oxidant compounds and shed light on the relative roles of catalase and of glutathione in the detoxification of hydrogen peroxide.

The role of $\mathrm{H}_{2} \mathrm{O}_{2}$ in oxidative hemolysis. As a class, compounds (such as aniline dyes, sulfonamides, and antimalarials) that cause Heinz body hemolytic anemias are capable of acting as catalysts in oxidation-reduction systems $(1,6,7,2)$. The essence of this process is the transfer of electrons from cellular components to molecular oxygen, with the resulting progressive oxidation of thiols and of hemoglobin $(2,3)$, culminating in the granular precipitation of hemoglobin into Heinz bodies $(2,4)$. It is debated, however, whether the ultimate agent of oxidative injury is the partially oxidized drug (e.g., a semiquinone) or the partially reduced oxygen (i.e., hydrogen peroxide), since both may be formed during the reaction and since both function as oxidizing free radicals. This question assumes importance since there exist natural systems, catalase and peroxidases, for detoxifying the latter, and deficiencies thereof might predispose toward hemolytic anemia. Tarlov and colleagues $(12,41)$ have suggested that hypocatalasemia and circulating "anticatalase" factors that occur after the ingestion of oxidant drugs might be crucial in oxidative hemolysis. Cohen and Hochstein, on the other hand, have emphasized the finding of Keilin and Hartree (16) that catalase is relatively inefficient in decomposing low concentrations of $\mathrm{H}_{2} \mathrm{O}_{2}$ and have demonstrated that continuous, low levels (less than $10^{-6} \mathrm{M}$ ) of $\mathrm{H}_{2} \mathrm{O}_{2}$, as are obtained in a well-diffusion system (11), will cause oxidative damage to erythrocytes regardless of normal levels of catalase. Since glucose protects erythrocytes against low levels of $\mathrm{H}_{2} \mathrm{O}_{2}$, unless the cells are deficient in G6PD (11), Cohen and Hochstein have concluded (17) that low levels of $\mathrm{H}_{2} \mathrm{O}_{2}$ are detoxified almost entirely by way of Mills' glutathione peroxidase with resultant stimulation of the HMP shunt mechanism. In normal erythrocytes the peroxidation of GSH accelerates the HMP shunt by generating TPN during the reduction of oxidized glutathione by glutathione reductase.

A major difficulty in assessing experimentally the relative participation of catalase in forefending 
oxidative hemolysis in man is that the use of catalase inhibitors has been necessitated. The present studies reveal that the most commonly employed inhibitors, azide and cyanide, although comparable in their capacity to bind the ferriheme groups of catalase, differ in their other effects on erythrocyte metabolism. Thus azide accelerates the oxidation of glutathione and hemoglobin beyond the rate observed in genetically acatalasic cells (compare Figures 2 and 5) and concomitantly stimulates HMP shunt metabolism (39). It is noteworthy that studies of glutathione peroxidase in human erythrocytes have utilized relatively high levels of azide $(10,15,7,19)$. On the other hand, cyanide, besides inhibiting catalase, also tends to stabilize thiols against oxidation (42). Study of the erythrocytes of genetically acatalasic and hypocatalasic subjects, therefore, afforded a unique opportunity to explore these matters, without the complicating influence of nonspecific catalase inhibitors. By comparing normal and acatalasic erythrocytes, with and without glucose, it was possible to assess separately the relative detoxifying roles of catalase and of the HMPshunt mechanism (presumed to be GSH peroxidase). Four systems were assessed: 1) both mechanisms intact (normal cells with glucose); 2 ) only catalase active (normal cells without glucose) ; 3) only GSH peroxidase active (acatalasic cells with glucose); and 4) neither mechanism intact (acatalasic cells without glucose).

The present studies reveal that acatalasic erythrocytes are strikingly susceptible to $\mathrm{H}_{2} \mathrm{O}_{2}$ at all levels in vitro, whether $\mathrm{H}_{2} \mathrm{O}_{2}$ is added abruptly in large amounts or is added gradually in low amounts as by the well-diffusion method (11) or by generation during the coupled oxidation of ascorbic acid and hemoglobin (5). These cells were hypersusceptible as well to steady low levels of $\mathrm{H}_{2} \mathrm{O}_{2}$ generated endogenously during prolonged aerobic incubation. In the absence of glucose, low levels of $\mathrm{H}_{2} \mathrm{O}_{2}$ initially caused oxidation of GSH followed by the formation of methemoglobin, sulfhemoglobin, and the precipitation of hemoglobin (as Heinz bodies) in acatalasic but not in normal erythrocytes. In the presence of glucose these changes were suppressed. Thus the capacity of acatalasic erythrocytes to compensate for their enzymatic deficiency requires glucose-consuming metabolism, and with low levels of $\mathrm{H}_{2} \mathrm{O}_{2}$ this compensation is complete. In the present studies the underlying hypersusceptibility of these cells to oxidative damage was unmasked by depriving them of glucose. However, their inherent vulnerability to oxidation was apparent even in the presence of glucose as evidenced by their increased "resting" HMP shunt activity and by the further inordinate acceleration thereof when these cells were exposed to $\mathrm{H}_{2} \mathrm{O}_{2}$. Although direct evidence is lacking that increased HMP shunt activity in catalase-deficient erythrocytes reflects accumulation of $\mathrm{H}_{2} \mathrm{O}_{2}$, this inference is supported by the findings: 1 ) that erythrocytes exposed to a variety of $\mathrm{H}_{2} \mathrm{O}_{2}$-generating systems in vitro manifest heightened HMP shunt metabolism $(39)$; 2) that the enzymatic sequence whereby such a metabolic response might occur has been described (10); and 3) that the necessary enzymes for this response (glutathione peroxidase and glutathione reductase) have been demonstrated in erythrocytes $(10,15,17,19)$. Furthermore, since normal erythrocytes were uninjured by low levels of $\mathrm{H}_{2} \mathrm{O}_{2}$, and since their metabolism was not significantly affected, it seems reasonable to conclude that catalase is a primary line of defense against $\mathrm{H}_{2} \mathrm{O}_{2}$ in the erythrocyte. Even half of the level of catalase appeared sufficient, for the heterozygotic individuals were normally resistant to $\mathrm{H}_{2} \mathrm{O}_{2}$. Only when catalase was virtually absent as in homozygous individuals was there evidence of a compensatory HMP shunt stimulation. Since this defensive response was little affected by fluoride, but markedly inhibited by the GSHblocking compound, NEM, the mechanism of this second line of defense against $\mathrm{H}_{2} \mathrm{O}_{2}$ is presumed to be through the $\mathrm{GSH}$ peroxidase mechanism described by others $(10,15,17,19)$. Thus, in acatalasia, the oxidative challenge of $\mathrm{H}_{2} \mathrm{O}_{2}$, whether spontaneously generated or drug-induced, both stimulates and is offset by hexosemonophosphate shunt activation.

It was possible in these studies to "assay" hemolytic drugs for their dependence on peroxide generation by noting their effect on acatalasic cells. Thus, the established ability of ascorbic acid to form $\mathrm{H}_{2} \mathrm{O}_{2}$ stoichiometrically during its coupled oxidation with oxyhemoglobin was attested to by finding that low levels of ascorbic acid caused methemoglobin selectively in acatalasic erythrocytes. With this assay, acatalasic cells were found 
not to be hypersusceptible to freshly prepared primaquine. If altered, however, by storage or ultraviolet irradiation, this drug acquired the capacity to generate hydrogen peroxide, as inferred from these studies. It is of interest that Carson (43) had noted an enhanced oxidative activity of primaquine after subjecting it to ultraviolet irradiation. On the other hand, acetylphenylhydrazine, a prototype of compounds that induce Heinz body hemolytic syndromes, produced oxidative injury equally in normal and in acatalasic erythrocytes. Thus, it did not appear to act through generating $\mathrm{H}_{2} \mathrm{O}_{2}$. Furthermore, previous studies (2) have shown that after the inhibition of catalase by cyanide, oxidative damage of hemoglobin treated with acetylphenylhydrazine is diminished, rather than abetted, suggesting further that $\mathrm{H}_{2} \mathrm{O}_{2}$ is not involved in the action of this drug.

The role of catalase under physiologic conditions and during autoxidation. As compared to normal cells, fresh erythrocytes from subjects with acatalasia showed heightened HMP shunt activity, with the oxidation of glucose-1- $\mathrm{C}^{14}$ proceeding at over three times the normal rate (Table IV). Thus, even at the very low levels of $\mathrm{H}_{2} \mathrm{O}_{2}$ generated endogenously in erythrocyte suspensions in vitro, a compensatory acceleration of the HMP shunt was required to offset the absence of catalase. In confirmation of this, acatalasic cells were found to be more "GSH unstable" than normal on sterile incubation without glucose, and they more rapidly manifested the hemoglobin oxidation and Heinz body formation that occur in erythrocytes on sterile incubation for several days (2). Since acatalasic erythrocytes depend constantly on heightened HMP shunt activity and since enzymes of this pathway diminish with cell age, it might be predicted that cell survival would be shortened if $\mathrm{H}_{2} \mathrm{O}_{2}$ is involved in cellular aging. Whether such is the case is uncertain from the present studies with $\mathrm{Cr}^{51}$, for this method is not dependable in evaluating relatively slight reductions in erythrocyte lifespan. It is apparent, however, that erythrocyte lifespan is not markedly diminished.

It seems clear from these studies that catalase in erythrocytes is a first line of defense against $\mathrm{H}_{2} \mathrm{O}_{2}$ but that under most circumstances it is dispensable. In its absence, $\mathrm{H}_{2} \mathrm{O}_{2}$ is dissipated primarily by the oxidation of GSH through the ac- tion of a glutathione peroxidase, and in response to this the metabolism of glucose through the HMP shunt is necessarily increased. Situations in which both catalase and the HMP shunt are markedly deficient would presumably be lethal.

\section{Summary}

The role of peroxides in erythrocyte aging and in drug-induced hemolysis and the effects of $\mathrm{H}_{2} \mathrm{O}_{2}$ on the thiol and glucose metabolism of erythrocytes were investigated in studies performed in several members of a Swiss family with hereditary acatalasia.

An assay dependent on the inordinate sensitivity of acatalasic erythrocytes to $\mathrm{H}_{2} \mathrm{O}_{2}$ demonstrated that ascorbic acid, hydroquinone, and aged primaquine generated $\mathrm{H}_{2} \mathrm{O}_{2}$ in vitro. Fresh primaquine and acetylphenylhydrazine did not.

Despite in vitro sensitivity to $\mathrm{H}_{2} \mathrm{O}_{2}$, the survival in vivo of $\mathrm{Cr}^{51}$-labeled acatalasic erythrocytes was not apparently curtailed either before or during the ingestion of large quantities of primaquine or ascorbic acid.

Acatalasic erythrocytes metabolized glucose through the hexosemonophosphate (HMP) shunt at three times the normal rate and increased this rate many times when exposed to levels of peroxide-generating drugs that had negligible effect on normal erythrocytes. Excessive shunt activity resulted from the peroxidation of glutathione, blockade of which by $N$-ethylmaleimide produced striking oxidative injury to acatalasic but not to normal erythrocytes. When erythrocytes lacked both their HMP shunt and catalase, oxidative damage by $\mathrm{H}_{2} \mathrm{O}_{2}$ was greater than with either deficiency alone.

These findings indicate that $\mathrm{H}_{2} \mathrm{O}_{2}$ is not involved in oxidative hemolysis induced by acetylphenylhydrazine and its congeners, although it is generated on standing by primaquine. In acatalasia, the oxidative challenge of $\mathrm{H}_{2} \mathrm{O}_{2}$ whether spontaneously generated or drug-induced, is dissipated by glutathione peroxidation. Therefore, $\mathrm{H}_{2} \mathrm{O}_{2}$ both stimulates and is offset by hexosemonophosphate shunt activation. In the normal erythrocyte, this mechanism and catalasic decomposition combine to prevent oxidative injury; when both mechanisms are overcome, $\mathrm{H}_{2} \mathrm{O}_{2}$ induces irreversible oxidative damage. 


\section{Acknowledgments}

We are deeply indebted to Professor A. Vannotti, Dr. Felber, Dr. Lemarchand-Béraud, and Dr. Jeunet of the Hôpital Cantonal, Clinique Médicale Universitaire, Lausanne, Switzerland, in whose laboratories these observations were made and without whose exceptional hospitality and continued assistance these studies could not have been performed.

\section{References}

1. Emerson, C. P., T. H. Ham, and W. B. Castle. Hemolytic action of certain organic oxidants derived from sulfanilamide, phenylhydrazine and hydroquinone (abstract). J. clin. Invest. 1941, 20, 451.

2. Jandl, J. H., L. K. Engle, and D. W. Allen., Oxidative hemolysis and precipitation of hemoglobin. I. Heinz body anemias as an acceleration of red cell aging. J. clin. Invest. 1960, 39, 1818.

3. Allen, D. W., and J. H. Jandl. Oxidative hemolysis and precipitation of hemoglobin. II. Role of thiols in oxidant drug action. J. clin. Invest. 1961, 40, 454.

4. Harley, J. D., and A. M. Mauer. Studies on the formation of Heinz bodies. II. The nature and significance of Heinz bodies. Blood 1961, 17, 418.

5. Lemberg, R., and J. W. Legge. Hematin Compounds and Bile Pigments; Their Constitution, Metabolism, and Function. New York, Interscience, 1949.

6. Beaven, G. H., and J. C. White. Oxidation of phenylhydrazines in the presence of oxyhæmoglobin and the origin of Heinz bodies in erythrocytes. Nature (Lond.) 1954, 173, 389.

7. Emerson, C. P., T. H. Ham, and W. B. Castle. The influence of resonating organic compounds on the integrity of red cells in Conference on the Preservation of the Formed Elements and of the Proteins of the Blood. Washington, D. C., American National Red Cross, 1949, p. 114.

8. Bingold, K. Die Niere als blutzerstörendes Organ. Klin. Wschr. 1933, 12, 1201.

9. Heubner, W. Methämoglobin, Innenkörper der Erythrocyten und Anämie. Klin. Wschr. 1941, 20, 137.

10. Mills, G. C., and H. P. Randall. Hemoglobin catabolism. II. The protection of hemoglobin from oxidative breakdown in the intact erythrocyte. $\mathrm{J}$. biol. Chem. 1958, 232, 589.

11. Cohen, G., and P. Hochstein. Glucose-6-phosphate dehydrogenase and detoxification of hydrogen peroxide in human erythrocytes. Science 1961, 134, 1756.

12. Tarlov, A. R., G. J. Brewer, P. E. Carson, and A. S. Alving. Primaquine sensitivity. Glucose-6-phosphate dehydrogenase deficiency: an inborn error of metabolism of medical and biological significance. Arch. intern. Med. 1962, 109, 209.
13. Cohen, G., and P. Hochstein. Primaquine-induced generation of hydrogen peroxide in erythrocytes (abstract). Blood 1962, 20, 785.

14. Foulkes, E. C., and R. Lemberg. The formation of choleglobin and the role of catalase in the erythrocyte. Proc. roy. Soc. B 1949, 136, 435.

15. Mills, G. C. Hemoglobin catabolism. I. Glutathione peroxidase, an erythrocyte enzyme which protects hemoglobin from oxidative breakdown. J. biol. Chem. 1957, 229, 189.

16. Keilin, D., and E. F. Hartree. Properties of catalase. Catalysis of coupled oxidation of alcohols. Biochem. J. 1945, 39, 293.

17. Cohen, G., and P. Hochstein. Glutathione peroxidase: the primary agent for the elimination of hydrogen peroxide in erythrocytes. Biochemistry 1963, 2, 1420.

18. Beutler, E. Drug-induced hemolytic anemia (primaquine sensitivity) in The Metabolic Basis of Inherited Disease, J. B. Stanbury, J. B. Wyngaarden, and D. S. Fredrickson, Eds. New York, McGraw-Hill, 1960, p. 1031.

19. Hill, A. S., Jr., A. Haut, G. E. Cartwright, and M. M. Wintrobe. The role of nonhemoglobin proteins and reduced glutathione in the protection of hemoglobin from oxidation in vitro. J. clin. Invest. 1964, 43, 17.

20. Szeinberg, A., and P. A. Marks. Substances stimulating glucose catabolism by the oxidative reactions of the pentose phosphate pathway in human erythrocytes. J. clin. Invest. 1961, 40, 914.

21. Jacob, H. S., and J. H. Jandl. Effects of sulfhydryl inhibition on red blood cells. I. Mechanism of hemolysis. J. clin. Invest. 1962, 41, 779.

22. Jacob, H. S., and J. H. Jandl. Effects of sulfhydryl inhibition on red blood cells. II. Studies in vivo. J. clin. Invest. 1962, 41, 1514.

23. Jacob, H. S., S. H. Ingbar, and J. H. Jandl. Studies of oxidative hemolysis in hereditary acatalasia (abstract). J. clin. Invest. 1964, 43, 1259.

24. Aebi, H., J. P. Heiniger, R. Bütler, and A. Hässig. Two cases of acatalasia in Switzerland. Experientia 1961, 17, 466.

25. Takahara, S. Progressive oral gangrene due to acatalasemia. Laryngoscope 1954, 64, 685.

26. Takahara, S. Progressive oral gangrene probably due to lack of catalase in the blood (acatalasæmia). Report of nine cases. Lancet 1952, 2, 1101.

27. Feinstein, R. N. Perborate as substrate in a new assay of catalase. J. biol. Chem. 1949, 180, 1197.

28. Beers, R. F., Jr., and I. W. Sizer. A spectrophotometric method for measuring the breakdown of hydrogen peroxide by catalase. J. biol. Chem. 1952, 195, 133.

29. Aebi, H., F. Jeunet, R. Richterich, H. Suter, R. Bütler, J. Frei, and H. R. Marti. Observations in two Swiss families with acatalasia. Enzymol. biol. Clin. (Basel) 1963, 2, 1.

30. Von Euler, H., and K. Josephson. Uber Katalase. I. Justus Liebigs Ann. Chem. 1927, 452, 158. 
31. Evelyn, K. A., and H. T. Malloy. Microdetermination of oxyhemoglobin, methemoglobin, and sulfhemoglobin in a single sample of blood. J. biol. Chem. 1938, 126, 655.

32. Scholz, R., H. Schmitz, T. H. Bücher, and J. O. Lampen. Uber die Wirkung von Nystatin auf Bäckerhefe. Biochem. Z. 1959, 331, 71.

33. Nelson, N. A photometric adaptation of the Somogyi method for the determination of glucose. J. biol. Chem. 1944, 153, 375.

34. Huggett, A., St. G., and D. A. Dixon. Use of glucose oxidase, peroxidase, and o-dianisidine in determination of blood and urinary glucose. Lancet 1957, 2, 368.

35. Grunert, R. R., and P. H. Phillips. A modification of the nitroprusside method of analysis for glutathione. Arch. Biochem. 1951, 30, 217.

36. Beutler, E. The glutathione instability of drugsensitive red cells. A new method for the in vitro detection of drug sensitivity. J. Lab. clin. Med. 1957, 49, 84.
37. Jacob, H. S., and J. H. Jandl. Increased cell membrane permeability in the pathogenesis of hereditary spherocytosis. J. clin. Invest. 1964, 43, 1704.

38. Jandl, J. H., M. S. Greenberg, R. H. Yonemoto, and W. B. Castle. Clinical determination of the sites of red cell sequestration in hemolytic anemias. J. clin. Invest. 1956, 35, 842.

39. Jacob, H. S., and J. H. Jandl. Effects of sulfhydryl inhibition on red blood cells. III. The role of glutathione in the regulation of the hexose monophosphate pathway. In preparation.

40. Jandl, J. H., and H. S. Jacob. Unpublished observations.

41. Tarlov, A. R., and R. W. Kellermeyer. The hemolytic effect of primaquine. XI. Decreased catalase activity in primaquine-sensitive erythrocytes. J. Lab. clin. Med. 1961, 58, 204.

42. Barron, E. S. G. Thiol groups of biological importance. Advanc. Enzymol. 1951, 11, 201.

43. Carson, P. E. Unpublished observations as quoted in reference 12 . 